\title{
Characterization of $\beta$-Glucosidase Produced by Aspergillus niger under Solid-State Fermentation and Partially Purified Using MANAE-Agarose
}

\author{
Anderson Baraldo Junior, ${ }^{1,2}$ Diogo G. Borges, ${ }^{1}$ \\ Paulo W. Tardioli, ${ }^{1}$ and Cristiane S. Farinas ${ }^{1,2}$ \\ ${ }^{1}$ Departamento de Engenharia Química, Universidade Federal de São Carlos, Rodovia Washington Luiz km 235, \\ 13565-905 São Carlos, SP, Brazil \\ ${ }^{2}$ Embrapa Instrumentação, Rua XV de Novembro 1452, 13560-970 São Carlos, São Paulo, SP, Brazil \\ Correspondence should be addressed to Cristiane S. Farinas; cristiane.farinas@embrapa.br
}

Received 11 December 2013; Accepted 10 March 2014; Published 1 April 2014

Academic Editor: Goetz Laible

Copyright (C) 2014 Anderson Baraldo Junior et al. This is an open access article distributed under the Creative Commons Attribution License, which permits unrestricted use, distribution, and reproduction in any medium, provided the original work is properly cited.

\begin{abstract}
$\beta$-Glucosidase (BGL) is a hydrolytic enzyme with specificity for a wide variety of glycoside substrates, being an enzyme with a large range of biotechnological applications. However, enzyme properties can be different depending both on the microorganism and the cultivation procedure employed. Therefore, in order to explore potential biocatalytical applications of novel enzymes, their characterization is essential. In this work, a BGL synthesized by a selected strain of Aspergillus niger cultivated under solid-state fermentation (SSF) was partially purified and fully characterized in terms of optimum $\mathrm{pH}$, temperature, and thermostability. The single-step purification using MANAE-agarose in a chromatographic column yielded an enzyme solution with specific activity (17.1 IU/mg protein) adequate for the characterization procedures. Electrophoresis SDS-PAGE and size-exclusion chromatography analysis resulted in an estimated molecular mass of $60 \mathrm{kDa}$. Higher enzyme activities were found in the range between 40 and $65^{\circ} \mathrm{C}$ and between $\mathrm{pH} 4$ and 5.5, indicating an interesting characteristic for application in the hydrolysis of lignocellulosic biomass for biofuels production. Thermostability studies of purified BGL resulted in half-lives at $37^{\circ} \mathrm{C}$ of $56.3 \mathrm{~h}$ and at $50^{\circ} \mathrm{C}$ of $5.4 \mathrm{~h}$. These results provide support for further studies of this enzyme towards revealing its potential biotechnological applications.
\end{abstract}

\section{Introduction}

The bioconversion of lignocellulosic materials into fermentable sugars requires a multienzymatic system containing cellulases, xylanases, and other accessory enzymes [1]. This enzymatic cocktail is one of the most costly inputs affecting the economic viability of the biochemical route for biomass conversion into biofuels and other chemicals [2]. In this process, cellulases act synergistically in the hydrolysis of cellulose: endoglucanases and exoglucanases or cellobiohydrolases (CBHs) act directly on the cellulose fiber, while $\beta$-glucosidase (BGL) hydrolyzes oligosaccharides and cellobiose into glucose [3]. The adequate proportion of each of these enzymes is crucial for an efficient hydrolysis, since the end product of $\mathrm{CBH}$ activity, which is cellobiose, is a product inhibitor for these enzymes [4-6]. Thus, BGL activity is important towards reducing inhibition effects. More importantly, cellobiose needs to be further degraded into the simple sugar glucose before it can be utilized by conventional yeasts for ethanol fermentation [7].

Most commercial cellulases are produced by filamentous fungi of the genera Trichoderma and Aspergillus [8]. However, the amount of BGL secreted by Trichoderma is not sufficient for an efficient biomass conversion [5], since the extent of cellulose conversion into glucose is dependent upon the amount of active BGL enzymes. On the other hand, Aspergillus strains, such as Aspergillus niger, has been used for BGL production that is often used as a supplementation of commercial enzymatic cocktails $[4,5]$. Besides, A. niger is prized in the industry for its high fermentation capacity, 
elevated levels of proteins secreted, and the variety of enzymes produced for diverse applications, including a combination of enzymes for degradation of plant cell wall polysaccharides $[9,10]$. Thus, production, purification, and characterization of $A$. niger BGL enzymes arise as important steps throughout this application.

The purification and characterization of BGL produced from different sources have been previously described in the literature using a range of different techniques [4, 11-18]. Nevertheless, most of the purification procedures include a sequence of steps that often results in a reduced recovery value or even some unwanted modification in the enzyme that can lead to activity loss. In order to preserve enzymatic activity it is necessary to reduce the purification steps and to produce the enzymes in a more concentrated medium. In this sense, the use of solid-state fermentation (SSF) is particularly advantageous for enzyme production, since the enzymes are produced in a more concentrated form when compared to submerged fermentation [19]. Given the potential of $A$. niger for BGL production there is a great interest in the development of efficient purification protocols and its characterization.

Here, we studied the purification and characterization of BGL produced by a selected strain of the filamentous fungi $A$. niger cultivated under solid-state fermentation. The purification of BGL from the enzymatic extract was initially evaluated using two different adsorbents (MANAE-agarose and Glucose-agarose) under batch experiments. Purification was further studied using a chromatographic column with MANAE-agarose. The partially purified $\beta$-glucosidase was thoroughly characterized in terms of the variables $\mathrm{pH}$ and temperature by using response surface methodology. The enzyme thermostabilities at 37 and $50^{\circ} \mathrm{C}$ were also evaluated.

\section{Materials and Methods}

2.1. Microorganism. The microorganism used in this study was the wild-type strain $A$. niger 12 from the Embrapa Food Technology collection (Rio de Janeiro, Brazil). Microorganism activation was carried out in basic medium agar slants incubated for 7 days at $32^{\circ} \mathrm{C}$ [20]. After this period, conidia were harvested by adding $10 \mathrm{~mL}$ of $0.1 \%$ Tween- 80 to the slant.

\subsection{SSF Cultivation Conditions. Solid-state fermentation cul-} tivations were carried out as described in [21]. Briefly, $500 \mathrm{~mL}$ Erlenmeyer flasks containing $10 \mathrm{~g}$ of wheat bran with a moisture level of $60 \%$ (adjusted with $0.9 \%$ (w:v) ammonium sulfate solution in $0.1 \mathrm{~mol} / \mathrm{L} \mathrm{HCl}$ ) were sterilized and then inoculated with a suspension of $10^{7}$ spores per gram of solid medium. Cultivations were carried out at $32^{\circ} \mathrm{C}$ for 72 hours. After this period, the enzymes were extracted by adding $0.2 \mathrm{~mol} / \mathrm{L}$ acetate buffer at $\mathrm{pH} 4.5$. The samples were stirred at $120 \mathrm{rpm}$ for $1 \mathrm{~h}$ and the enzymatic solution was recovered by filtration. The recovered enzyme extracts were stored at $-18^{\circ} \mathrm{C}$ for further analysis. Monoaminoethyl-N-aminoethyl (MANAE) agarose gel was prepared as described by [22] using glyoxal supports which were prepared according to [23]. For preparation of MANAEagarose, to the support prepared from glyoxal-agarose, $200 \mathrm{~mL}$ of $2 \mathrm{M}$ ethylenediamine (EDA) solution at $\mathrm{pH} 10$ was added to a $35 \mathrm{~g}$ of glyoxal-agarose support. After $2 \mathrm{~h}$ of gentle agitation, sodium borohydride was added to a final concentration of $10 \mathrm{mg} / \mathrm{mL}$. Again, after $2 \mathrm{~h}$ of gentle agitation, the MANAE-agarose support was washed successively with $100 \mathrm{mM}$ acetate buffer $\mathrm{pH} 4,100 \mathrm{mM}$ borate buffer $\mathrm{pH} 9$ and finally distilled water.

Purification of BGL present in the crude enzymatic extract was initially evaluated using batch experiments undertaken in $50 \mathrm{~mL}$ flasks. For this, the MANAE-agarose gel previously described was added to the enzymatic solution at a $1: 2(\mathrm{~m} / \mathrm{v})$ ratio. This suspension was kept under gently agitation at $25^{\circ} \mathrm{C}$. Total protein and enzymatic activity were periodically measured in the supernatant. After the period considered sufficient for equilibrium to be achieved, the MANAE-agarose gel was filtered and washed with a $5 \mathrm{mM}$ phosphate buffer at $\mathrm{pH}$ 7.0. The adsorbed enzyme was released from the support by incubation with a gradient of 150 to $600 \mathrm{mM} \mathrm{NaCl}$ solution at $\mathrm{pH}$ 7.0.

For the chromatographic assay, a $25 \mathrm{~mL}$ column was packed with $5 \mathrm{~g}$ of the adsorbent MANAE-agarose and equilibrated with the equilibration buffer $(5 \mathrm{mM}$ phosphate buffer at $\mathrm{pH}$ 7.0). Enzymatic extract ( $3 \mathrm{~mL}$ ) was fed into the column, followed by a washing step with this same equilibration buffer. Elution was undertaken with a $\mathrm{NaCl}$ step gradient using the equilibration buffer containing 150 to $600 \mathrm{mM} \mathrm{NaCl}$. The flow rate during all procedures was $0.4 \mathrm{~mL} / \mathrm{min}$ and the $3.0 \mathrm{~mL}$ fractions collected were analyzed for total protein and BGL activity.

\section{4. $\beta$-Glucosidase Partial Purification Using Glucose-Agarose.} Sepharose 6B-CL, acquired from Sigma (St. Louis, MO), was used as support for the biospecific affinity purification of BGL. The affinity support was derivatized by activation with bisoxirane following the protocol described by [24] and coupling the biospecific ligand glucose. Briefly, for the immobilization of the ligand glucose, the activated gel was washed with distilled water to remove excess dioxirane and stabilized for 5 minutes in a solution of $\mathrm{NaOH} 0.1 \mathrm{M}$. For each gram of activated and dried gel, $2 \mathrm{~mL}$ of $0.1 \mathrm{M} \mathrm{NaOH}$ containing 20\% (w/v) glucose was added and stirred for 16 hours at $45^{\circ} \mathrm{C}$. After immobilization of the ligand, the gel was washed with distilled water and sodium phosphate buffer $50 \mathrm{mM}, \mathrm{pH}$ 7, in order to eliminate unfixed glucose molecules. The gel was then stored at $4^{\circ} \mathrm{C}$ in the same buffer containing $0.1 \%(\mathrm{w} / \mathrm{v})$ sodium benzoate until use.

For the purification procedure, a suspension containing the BGL enzymatic complex and the affinity support (Agarose-Glucose) at a 1:2 (m/v) ratio was prepared. This suspension was maintained under gentle stirring for a time suitable for the maximum adsorption of the enzymes. Protein concentration and enzyme activity were monitored regularly in the supernatant. When the protein concentration in the supernatant and/or enzymatic activity became constant, the gel was filtered, washed with sodium phosphate buffer $5 \mathrm{mM}$, 
TABLE 1: Mass balance of $\beta$-glucosidase purification using MANAE-agarose and glucose-agarose supports in batch experiments.

\begin{tabular}{|c|c|c|c|c|c|c|c|}
\hline Adsorbent & $\begin{array}{l}\text { BGL feed } \\
\quad(\mathrm{IU})\end{array}$ & $\begin{array}{c}\text { BGL } \\
\text { adsorbed } \\
\text { (IU) }\end{array}$ & $\begin{array}{l}\text { Total protein } \\
\text { feed (mg) }\end{array}$ & $\begin{array}{l}\text { Total protein } \\
\text { adsorbed (mg) }\end{array}$ & $\begin{array}{l}\text { Initial specific } \\
\text { activity (IU/mg) }\end{array}$ & $\begin{array}{l}\text { Final specific } \\
\text { activity (IU/mg) }\end{array}$ & $\begin{array}{l}\text { Purification } \\
\text { factor }\end{array}$ \\
\hline MANAE-agarose & 78.6 & 27.7 & 10.2 & 2.1 & 7.7 & 20.1 & 2.6 \\
\hline Glucose-agarose & 44.9 & 12.3 & 7.8 & 2.8 & 5.8 & 7.5 & 1.3 \\
\hline
\end{tabular}

$\mathrm{pH} 7$, and resuspended into a small volume of the same buffer. For the elution step, the gel was resuspended with a supersaturated solution of glucose (maximum of $1 \mathrm{~mol} / \mathrm{L}$ glucose) and was left under mild stirring for $30 \mathrm{~min}$. The glucose concentration of the medium was gradually increased until the protein concentration of the supernatant was equal to or near the protein concentration of the total suspension. At this point, it could be inferred that the maximum amount of the enzyme attached to the affinity support was eluted. However, with this process the enzyme is obtained and purified BGL eluted in a solution containing high concentrations of glucose ( $1 \mathrm{~mol} / \mathrm{L}$ glucose). As glucose can act as an inhibitor in the reaction catalyzed by $\mathrm{BG}$, a filtration process was made to remove this glucose solution. The solution was placed into a $10 \mathrm{kDa}$ ultrafiltration system and centrifuged at $10.000 \mathrm{~g}$ at $4^{\circ} \mathrm{C}$, so that the glucose could pass through the filter, while the protein fraction remained. In the final solution without glucose, BGL activity and total protein were measured and the purification factor was calculated.

2.5. Determination of Optimum $\mathrm{pH}$ and Temperature. A full factorial design followed by response surface analysis was used to evaluate the effect of temperature and $\mathrm{pH}$ on BGL activity. Optimum $\mathrm{pH}$ and temperature for BGL were determined by assaying the corresponding activity at different temperatures (from 23 to $87^{\circ} \mathrm{C}$ ) and $\mathrm{pH}$ values (from 2.4 to 6.6), selected according to the experimental design conditions. Cellulase enzymes usually have optimum activity at $\mathrm{pH}$ around 5.0 and temperature of $50^{\circ} \mathrm{C}$. Therefore, $\mathrm{pH}$ and temperature values around these ranges were selected. The experimental design selected was a central composite design comprising eleven runs, corresponding to four cube points, four axial points, and three central points, with the experiments carried out in a random order. The dependent variable (response) was BGL activity. The Statistica software (Statsoft, version 7. 0) was used to analyze the experimental data, the generation of the ANOVA (analysis of variance) data, and the plotting of response surfaces.

A second-order polynomial model of the form of (1) was used to fit the data:

$$
Y=\beta_{0}+\beta_{1} X_{1}+\beta_{2} X_{2}+\beta_{11} X_{1}^{2}+\beta_{22} X_{2}^{2}+\beta_{12} X_{1} X_{2},
$$

where $Y$ is the predicted response variable; $\beta_{0}$ is the intercept term; $\beta_{1}$ and $\beta_{2}$ are the linear coefficients; $\beta_{11}$ and $\beta_{22}$ are the squared coefficients; $\beta_{12}$ is the interaction coefficients; and $X_{1}$ and $X_{2}$ are the coded independent variables representing the $\mathrm{pH}$ and the temperature, respectively.

2.6. Enzyme Thermostability. BGL thermostability at temperatures of 37 and $50^{\circ} \mathrm{C}$ was evaluated by measuring the residual enzyme activity after each $24 \mathrm{~h}$ during a $96 \mathrm{~h}$ total incubation period in the absence of substrate. The enzyme's halflives were calculated according to [30] using the single-step nonfirst-order model proposed by [31] to fit the experimental data. The activity time expression used (see (2)) relates the activity $(a)$ to the parameter $k_{1}$, the first-order deactivation rate constant, the parameter $\alpha_{1}$, and the long-term level of activity:

$$
a=\left(1-\alpha_{1}\right) \exp \left(-k_{1} \cdot t\right)+\alpha_{1}
$$

The two-parameter model was fitted to the residual activity data using the Levenberg-Marquardt method of iterative convergence, at 0.95 confidence level.

2.7. Analytical Measurements. BGL activity was determined by incubating a mixture of $1 \mathrm{~mL}$ of the appropriately diluted enzymatic extract and $1 \mathrm{~mL}$ of a $0.015 \mathrm{~mol} / \mathrm{L}$ solution of cellobiose (Sigma, USA) prepared in $0.05 \mathrm{~mol} / \mathrm{L}$ sodium citrate buffer $\mathrm{pH} 4.8$ as substrate for $30 \mathrm{~min}$ at $50^{\circ} \mathrm{C}$. The reaction was stopped by submersion in boiling water for $5 \mathrm{~min}$. The quantification of the glucose released was performed by using an enzymatic kit for glucose measurement (Laborlab, Brazil). Total protein was measured using the Bradford method [32]. Bovine serum albumin was used as standard. The protein molecular mass profiles were evaluated by SDS-PAGE electrophoresis conducted under denaturing conditions as described by [33]. Gels (15\%) were stained with Coomassie Blue. Size exclusion chromatography in a Superdex 200 100/300 GL (GE, USA) column was also used for molecular mass evaluation. The enzyme was eluted with $50 \mathrm{mM}$ phosphate buffer ( $\mathrm{pH} 7.0$ ) containing $15 \mathrm{mM} \mathrm{NaCl}$ at a flow rate of $0.5 \mathrm{~mL} / \mathrm{min}$.

\section{Results and Discussion}

3.1. BGL Production and Partial Purification. The purification of BGL present in the cellulolytic enzyme complex produced by the filamentous fungus $A$. niger grown on wheat bran under SSF was initially evaluated by carrying out batch experiments for both MANAE-agarose and glucose-agarose supports (Table 1). The purification factor using MANAEagarose was 2-folds higher than the one using Glucoseagarose. Even though the purification factors achieved using the two adsorbents were different, the analysis of both purified materials by size exclusion on a high resolution size exclusion column resulted in a single peak (Figure 1), demonstrating their effectiveness for BGL purification.

Based on these results, the support MANAE-agarose was selected for further studies of purification under dynamic 


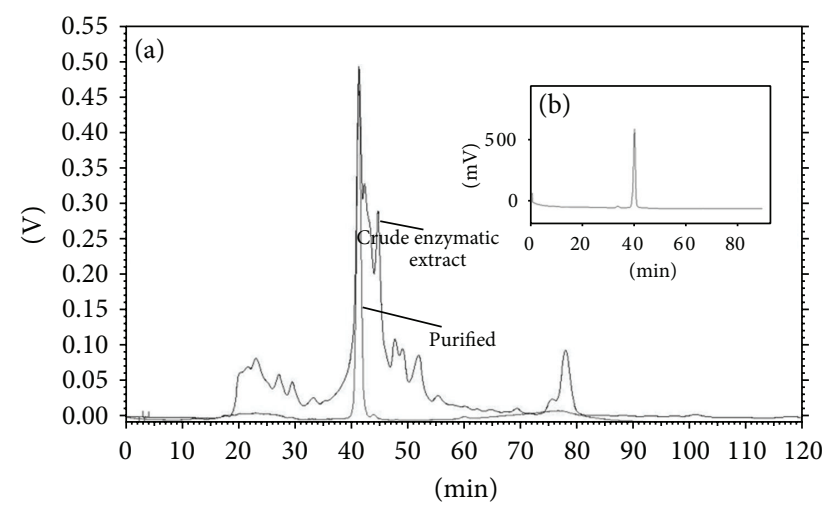

FIGURE 1: HPLC size-exclusion chromatograph of enzymatic extract before and after purification using MANAE-agarose (a) and glucoseagarose (b) supports in batch experiments.

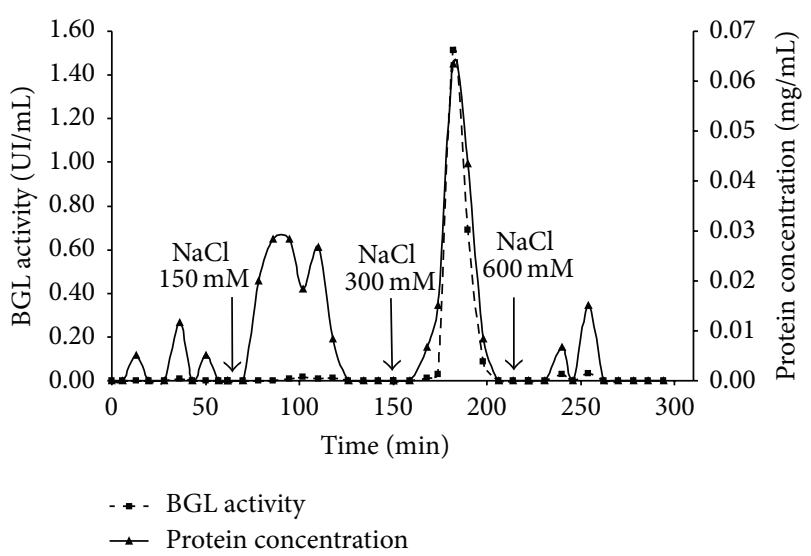

Figure 2: MANAE-agarose chromatogram for $\beta$-glucosidase purification. Feeding step: enzymatic extract produced by $A$. niger under SSF. Elution was carried out using a $\mathrm{NaCl}$ step gradient with $5 \mathrm{mM}$ citrate buffer $\mathrm{pH} 7.0$.

conditions using a chromatographic column. Figure 2 shows the chromatogram for BGL purification using a MANAEagarose loaded column and Table 2 shows the mass balance of BGL purification for the respective system. It can be observed that a considerable amount of total proteins and BGL was not adsorbed on the MANAE-agarose gel as it passed through the column during the feed and washing steps. Using a buffer solution of low ionic strength $(50 \mathrm{mM} \mathrm{NaCl})$, few proteins were desorbed and almost no BGL activity was presented in the elution samples. With a buffer solution of $150 \mathrm{mM}$ $\mathrm{NaCl}$, the desorption process showed an interesting result. It could be observed that, although a considerable amount of total proteins was desorbed, no BGL activity was shown in the samples, thereby indicating that at this ionic strength only minor proteins and contaminants are desorbed from the support. BGL was desorbed from MANAE-agarose by using a buffer of ionic strength of $300 \mathrm{mM}$. These samples were analyzed presenting a high BGL activity and total protein desorbed compared to the other ionic strengths buffers.
TABLE 2: Mass balance of $\beta$-glucosidase purification using MANAEagarose support in a chromatographic column.

\begin{tabular}{|c|c|c|c|c|}
\hline & \multicolumn{4}{|c|}{ MANAE-agarose } \\
\hline & \multicolumn{2}{|c|}{ Total protein } & \multicolumn{2}{|c|}{$\beta$-Glucosidase } \\
\hline & $\mathrm{mg}$ & $\%$ & IU & $\%$ \\
\hline Feeding & 2.95 & 100 & 33.08 & 100 \\
\hline Washed out & 1.96 & 66.4 & 25.08 & 75.8 \\
\hline \multicolumn{5}{|c|}{ Elution $\mathrm{NaCl}(\mathrm{mM})$} \\
\hline 50 & 0.07 & 2.4 & 0.03 & 0.1 \\
\hline 150 & 0.39 & 13.2 & 0.14 & 0.4 \\
\hline 300 & 0.41 & 13.9 & 7.00 & 21.2 \\
\hline 600 & 0.07 & 2.4 & 0.20 & 0.6 \\
\hline Total recovery & 2.90 & 98.3 & 32.5 & 98.2 \\
\hline
\end{tabular}

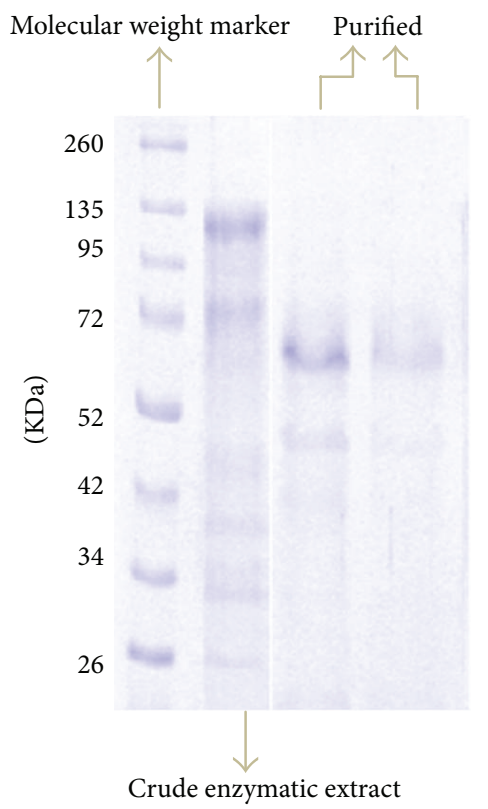

FIGURE 3: Electrophoresis profile of enzymatic extract after purification using MANAE-agarose packed column.

By using a MANAE-agarose chromatographic column for BGL purification, specific activity increases from $11.2 \mathrm{IU} / \mathrm{mg}$ in the crude enzymatic extract to $17.1 \mathrm{IU} / \mathrm{mg}$, considering the elution using $300 \mathrm{mM} \mathrm{NaCl}$. This corresponds to a purification factor close to 2. Nevertheless, the effectiveness of BGL purification under this condition can be verified in the SDSPAGE electrophoresis gel (Figure 3). Analysis of the enzyme by SDS-PAGE revealed a major band with an estimated molecular mass of $60 \mathrm{kDa}$. Size exclusion chromatography on a Superdex 200 high resolution column resulted in the elution of BGL as a peak also between 50 and $70 \mathrm{kDa}$ (data not shown). This result indicates that BGL may be present as a monomer in solution. This result is in agreement with the theoretical molecular mass of BGL (close to $75 \mathrm{kDa}$ ), according to [4]. 
3.2. Characterization of BGL from A. niger. The physicochemical characterization of enzymes is important in order to identify the performance of the enzyme under different work conditions. However, enzyme properties can be different depending on the microorganism producing them. Therefore, in order to explore potential biocatalytical applications of enzymes produced by different strains, the characterization of these enzymes is essential. Some of the enzyme properties considered important for production, purification, and application are its size/molecular weight, optimal $\mathrm{pH}$, and temperature for enzyme activity and stability. Described in the following sections is the characterization of a MANAEagarose partially purified BGL produced by a strain of Aspergillus niger cultivated under solid-state fermentation. Our previous results of BGL properties present in a crude enzymatic extract were used for comparison [21].

3.2.1. Effects of $p H$ and Temperature on BGL Activity. Initially, the effects of $\mathrm{pH}$ and temperature on BGL activity were evaluated as this characterization is important for selection of process conditions. The active sites on enzymes are frequently composed of ionizable groups which must be in the proper ionic form to maintain the conformation of the active site, bind the substrate, or catalyze the reaction. In terms of the temperature effect on enzymes activity, it is expected a faster velocity as the temperature rises, as an increase in temperature imparts more kinetic energy to the molecules resulting in more productive collisions per unit of time. However, if the molecule absorbs too much energy, the enzyme can be denatured and lose its catalytic activity [34].

Here, the $\mathrm{pH}$ and temperature effects on a partially purified BGL were evaluated by using the statistical design of experiments and response surface methodology analysis. Table 3 presents the results of the complete factorial design for BGL activities under the different conditions evaluated. Table 4 exhibits the coefficients of the mathematical model and statistical parameters. The quadratic effects of both $\mathrm{pH}$ and temperature on BGL activity were significant at $95 \%$ confidence limit $(P$-value $<0.05)$. Both variables showed a negative effect on BGL activity. The ANOVA analysis for BGL activity showed that the coefficient of correlation (0.9923) and the $F$ test (115.43 times higher than the listed $F$ value at $95 \%$ level of confidence, resp.) were very satisfactory for the prediction of the model used to describe the response surface plot of the enzyme activities as a function of $\mathrm{pH}$ and temperature (Figure 4).

The data analysis allowed defining an optimum range of temperature and $\mathrm{pH}$ for higher enzyme activity, as well as the degree of significance of each variable. The statistical analysis revealed that the optimum values of temperature for partially purified BGL were found to be in the range between $40^{\circ} \mathrm{C}$ and $65^{\circ} \mathrm{C}$, and the optimum $\mathrm{pH}$ range was found between 4 and 5.5. Higher experimental values of enzymatic activity were found at the condition of the central point, which is at $\mathrm{pH}$ 4.5 and $55^{\circ} \mathrm{C}$. This optimum range is in agreement with the results obtained for the BGL present in the crude enzymatic extract, as previously described in [21].

Several studies focusing on the characterization of BGL in terms of $\mathrm{pH}$ and temperature parameters have been made
TABLE 3: Experimental conditions and results of the statistical experimental design for $\beta$-glucosidase activity.

\begin{tabular}{lccc}
\hline Trial & $T\left({ }^{\circ} \mathrm{C}\right)$ & $\mathrm{pH}$ & $\beta$-Glucosidase $(\mathrm{IU} / \mathrm{mL})$ \\
\hline 1 & $80(1)$ & $6(1)$ & 0.028 \\
2 & $80(1)$ & $3(-1)$ & 0.027 \\
3 & $30(-1)$ & $6(1)$ & 0.056 \\
4 & $30(-1)$ & $3(-1)$ & 0.071 \\
5 & $87(1.41)$ & $4.5(0)$ & 0.092 \\
6 & $23(-1.41)$ & $4.5(0)$ & 0.175 \\
7 & $55(0)$ & $6.6(1.41)$ & 0.084 \\
8 & $55(0)$ & $2.4(-1.41)$ & 0.028 \\
9 & $55(0)$ & $4.5(0)$ & 0.971 \\
10 & $55(0)$ & $4.5(0)$ & 1.059 \\
11 & $55(0)$ & $4.5(0)$ & 1.034 \\
\hline
\end{tabular}

TABLE 4: Coefficient values and statistical analysis for $\beta$-glucosidase activity.

\begin{tabular}{|c|c|c|}
\hline & \multicolumn{2}{|c|}{$\beta$-Glucosidase } \\
\hline & Coefficients & $P$ value \\
\hline Mean* & 1.021 & 0.0000 \\
\hline$T$ & -0.024 & 0.2003 \\
\hline$T^{2^{*}}$ & -0.456 & 0.0000 \\
\hline $\mathrm{pH}$ & 0.008 & 0.6333 \\
\hline $\mathrm{pH}^{2 *}$ & -0.495 & 0.0000 \\
\hline$T \cdot \mathrm{pH}$ & 0.004 & 0.8670 \\
\hline$R$ & \multicolumn{2}{|c|}{0.9923} \\
\hline$F$ value & \multicolumn{2}{|c|}{514.81} \\
\hline$F_{\text {cal }} / F_{\text {listed }}$ & \multicolumn{2}{|c|}{115.43} \\
\hline
\end{tabular}

${ }^{*}$ Significant at 0.05 level; $R=$ coefficient of determination.

TABLE 5: Literature values for optimum $\mathrm{pH}$ and temperature of different BGL.

\begin{tabular}{lccc}
\hline \multicolumn{2}{l}{ Microorganism source Optimum pH } & $\begin{array}{c}\text { Optimum } \\
\text { temperature } \\
\left({ }^{\circ} \mathrm{C}\right)\end{array}$ & Reference \\
\hline Penicillium pinophilum & 5.0 & 60 & {$[12]$} \\
Penicillium funiculosum & 4.0 and 5.0 & 60 & {$[25]$} \\
Aspergillus glaucus & 3.6 & 60 & {$[16]$} \\
Aspergillus terreus & 5.0 & 60 & {$[26]$} \\
Aspergillus niger & 4.0 & 60 & {$[27]$} \\
Aspergillus niger & 4.5 & $60-70$ & {$[6]$} \\
Aspergillus niger & 4.5 & 55 & {$[18]$} \\
Aspergillus niger & 4.5 & 60 & {$[13]$} \\
Aspergillus niger & $4.5-5.0$ & $55-60$ & {$[28]$} \\
Aspergillus niger & 5.0 & 55 & {$[29]$} \\
Aspergillus niger & $4.0-5.5$ & $40-65$ & This work \\
\hline
\end{tabular}

due to a large interest in understanding the action of this enzyme under different conditions. The optimum $\mathrm{pH}$ and temperature of BGL from different sources are described in Table 5. The optimum $\mathrm{pH}$ ranges from 3.6 to 5.0, while the optimum temperature ranges from 55 to $70^{\circ} \mathrm{C}$. However, most 


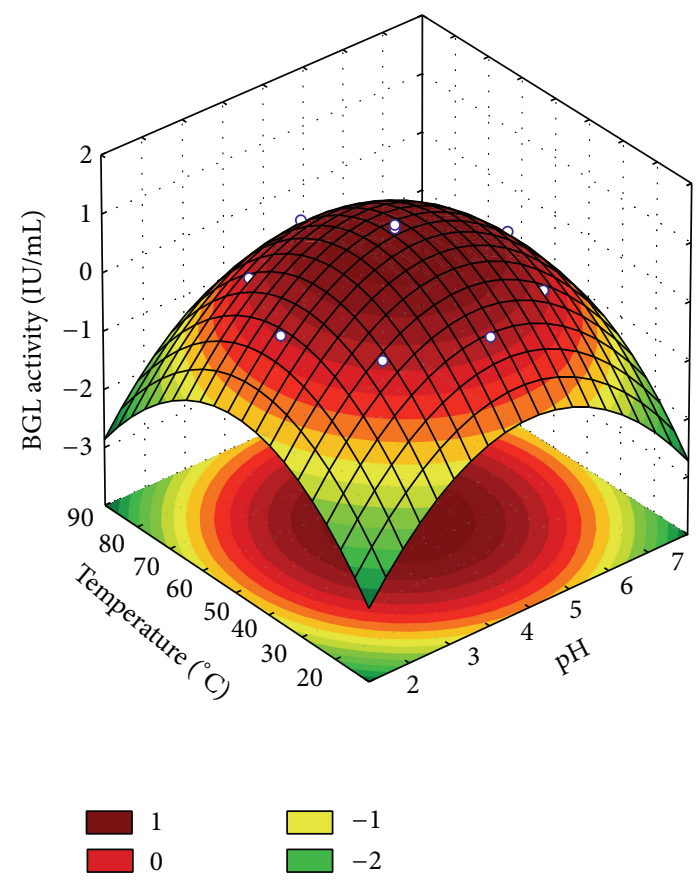

FIGURE 4: Surface response showing the $\mathrm{pH}$ and temperature effect on $\beta$-glucosidase activity partially purified using MANAE-agarose packed column.

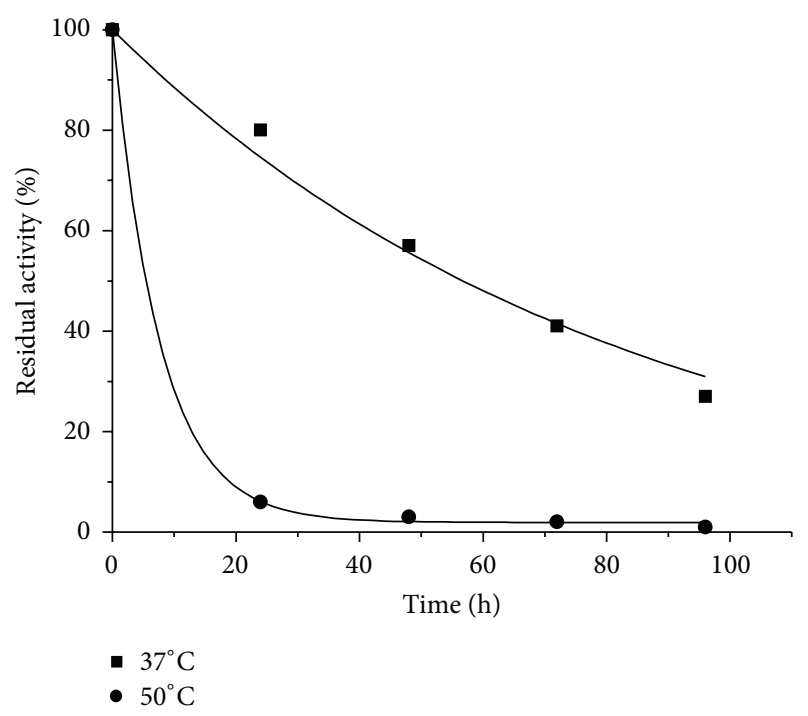

Figure 5: Thermostability at $37(\bullet)$ and $50^{\circ} \mathrm{C}(\boldsymbol{\square})$ of $\beta$-glucosidase activity partially purified using MANAE-agarose packed column.

of these studies describe the evaluation of one parameter at a time. Finding the optimal $\mathrm{pH}$ and temperature includes a study of both variables at the same time. In this context, the use of statistical experimental design followed by response surface methodology (RSM) to identify the optimal values of $\mathrm{pH}$ and temperature can be very effective to analyze the relationships among these parameters. The conventional method for optimizing a multivariable system analyzing one factor at a time does not access the interaction effects between
TABLE 6: Half-life values for BGL under different temperatures.

\begin{tabular}{lcccc}
\hline & \multicolumn{2}{c}{$\begin{array}{c}\text { BGL in the crude } \\
\text { extract }[21]\end{array}$} & \multicolumn{2}{c}{$\begin{array}{c}\text { Partially purified } \\
\text { BGL }\end{array}$} \\
\hline $\begin{array}{l}\text { Temperature } \\
\left({ }^{\circ} \mathrm{C}\right)\end{array}$ & $\mathbf{3 7}$ & $\mathbf{5 0}$ & 37 & $\mathbf{5 0}$ \\
$\alpha_{1}\left(\mathrm{~h}^{-1}\right)$ & 0.8408 & 0 & 0 & 0.0191 \\
$k_{1}$ & 0.0327 & 0.0047 & 0.0122 & 0.1316 \\
Half-life $(\mathrm{h})^{*}$ & 341.5 & 148.1 & 56.3 & 5.4 \\
\hline
\end{tabular}

${ }^{*}$ Half-lives calculated from the model equation.

the variables. This interaction can result in a synergistic effect, that is, a $\mathrm{pH}$ and temperature condition in which the enzymes have a higher activity value. Another advantage of using the statistical methodology was the definition of an optimum temperature and $\mathrm{pH}$ range, rather than a specific value, allowing more flexibility during process development.

The optimum range of temperature for partially purified $\mathrm{BGL}$, between 40 and $65^{\circ} \mathrm{C}$, and the optimum $\mathrm{pH}$ range, between 4 and 5.5, can be very interesting characteristics for application in the hydrolysis of lignocellulosic materials. For the simultaneous saccharification and fermentation process configuration, a compromise has to be found, since the optimal temperature for enzymatic hydrolysis is usually higher (around $55^{\circ} \mathrm{C}$ when using fungal enzymes) than that of fermentation by yeasts (around $30^{\circ} \mathrm{C}$ ) [35]. Therefore, an enzyme with this relatively broad range of optimum temperature would be of interest.

3.2.2. BGL Thermostability. Evaluation of enzyme thermostability is very important towards defining the optima range of process conditions in order to preserve the catalytic activity during the hydrolysis. Besides, advantages such as faster reaction rates, lower viscosity, and increased solubility of the substrate have been proposed for the use of thermostable enzymes in biotechnological processes [36]. Thermostable enzymes in the hydrolysis of lignocellulosic materials can also have several potential advantages: higher specific activity (decreasing the amount of enzyme needed), higher stability (allowing elongated hydrolysis times), and increased flexibility for the process configurations [37].

Thermostability of partially purified BGL at $37^{\circ} \mathrm{C}$ and $50^{\circ} \mathrm{C}$ was evaluated (Figure 5). These two temperatures were selected considering that the use of $37^{\circ} \mathrm{C}$ is an intermediate condition for a simultaneous saccharification and fermentation process configuration, since the yeast usually has an optimal temperature around $30^{\circ} \mathrm{C}$ and enzymes around $50^{\circ} \mathrm{C}$. The model proposed by [31] was used to fit the experimental data and the enzyme's half-lives were then calculated using the fitted model according to [30]. Table 6 shows the results of the model parameters $k_{1}$ and $\alpha_{1}$ and the half-life for BGL activity present in the crude enzyme extract and after the purification step. A higher stability at $37^{\circ} \mathrm{C}$ and $50^{\circ} \mathrm{C}$ was observed for BGL present in the crude extract in comparison to the partially purified enzyme (Table 6), showing that the purification procedure negatively influenced BGL thermostability. This result was rather unexpected since the purification 
procedure usually favors enzyme stability due to the removal of proteases and other proteins that could form aggregates with the molecule of interest.

A reduction in BGL stability after purification found in our results may be related to the removal of some stabilizing compound originally present in the medium. Nevertheless, it is important to note that this thermostability analysis is carried out exclusively for characterization purpose. In practice, different conditions such as the presence of the substrate and stabilizing agents can circumvent this characteristic.

\section{Conclusion}

The purification protocol used to purify BGL from the enzymatic extract obtained by the cultivation of Aspergillus niger under SSF was very efficient, since by using a MANAEagarose adsorbent it was possible to obtain a partially purified enzyme in a single purification step. To better understand the characteristics of this enzyme and extend the knowledge about its potential applications, a complete characterization in terms of optimum $\mathrm{pH}$ and temperature and thermostability was performed. The methodology employed here was very effective in estimating enzyme behavior under different $\mathrm{pH}$ and temperature conditions. Higher enzyme activities were found to be in the range between 40 and $65^{\circ} \mathrm{C}$ and between $\mathrm{pH} 4$ and 5.5. In terms of thermal stability, the enzymatic extract was found to be highly stable at both temperatures tested 37 and $50^{\circ} \mathrm{C}$ when present in the crude enzymatic extract, although the purification procedure showed a negative effect on BGL thermostability.

\section{Conflict of Interests}

The authors declare that there is no conflict of interests regarding the publication of this paper.

\section{Acknowledgment}

The authors would like to thank Embrapa, Fapesp, and CNPq, Brazil, for the financial support.

\section{References}

[1] Y.-H. Percival Zhang, M. E. Himmel, and J. R. Mielenz, "Outlook for cellulase improvement: screening and selection strategies," Biotechnology Advances, vol. 24, no. 5, pp. 452-481, 2006.

[2] S. Macrelli, J. Mogensen, and G. Zacchi, “Techno-economic evaluation of 2 nd generation bioethanol production from sugar cane bagasse and leaves integrated with the sugar-based ethanol process," Biotechnology for Biofuels, vol. 5, article 22, 2012.

[3] S. P. S. Chundawat, G. T. Beckham, M. E. Himmel, and B. E. Dale, "Deconstruction of lignocellulosic biomass to fuels and chemicals," Annual Review of Chemical and Biomolecular Engineering, vol. 2, no. 2, pp. 121-145, 2011.

[4] M. Chauve, H. Mathis, D. Huc, D. Casanave, F. Monot, and N. L. Ferreira, "Comparative kinetic analysis of two fungal $\beta$ glucosidases," Biotechnology for Biofuels, vol. 3, article 3, 2010.
[5] L. R. Lynd, P. J. Weimer, W. H. Van Zyl, and I. S. Pretorius, "Microbial cellulose utilization: fundamentals and biotechnology," Microbiology and Molecular Biology Reviews, vol. 66, no. 3, pp. 506-577, 2002.

[6] R. F. H. Dekker, "Kinetic, inhibition, and stability properties of a commercial beta -d-glucosidase (cellobiase) preparation from Aspergillus niger and its suitability in the hydrolysis of lignocellulose," Biotechnology and Bioengineering, vol. 28, no. 9, pp. 1438-1442, 1986.

[7] Z. L. Liu, S. A. Weber, and M. A. Cotta, "Isolation and characterization of a $\beta$-glucosidase from a clavispora strain with potential applications in bioethanol production from cellulosic materials," BioEnergy Research, vol. 6, no. 1, pp. 65-74, 2013.

[8] M. K. Bhat, "Cellulases and related enzymes in biotechnology," Biotechnology Advances, vol. 18, no. 5, pp. 355-383, 2000.

[9] D. Liu, R. Zhang, X. Yang et al., "Thermostable cellulase production of Aspergillus fumigatus Z5 under solid-state fermentation and its application in degradation of agricultural wastes," International Biodeterioration and Biodegradation, vol. 65, no. 5, pp. 717-725, 2011.

[10] R. P. de Vries and J. Visser, "Aspergillus enzymes involved in degradation of plant cell wall polysaccharides," Microbiology and Molecular Biology Reviews, vol. 65, no. 4, pp. 497-522, 2001.

[11] L. Chen, N. Li, and M.-H. Zong, "A glucose-tolerant $\beta$ glucosidase from Prunus domestica seeds: purification and characterization," Process Biochemistry, vol. 47, no. 1, pp. 127$132,2012$.

[12] A.-R. Joo, M. Jeya, K.-M. Lee et al., "Production and characterization of $\beta$-1,4-glucosidase from a strain of Penicillium pinophilum," Process Biochemistry, vol. 45, no. 6, pp. 851-858, 2010.

[13] G. Spagna, D. Romagnoli, M. Angela, G. Bianchi, and P. G. Pifferi, "A simple method for purifying glycosidases: $\alpha$-L-arabinofuranosidase and $\beta$-D-glucopyranosidase from Aspergillus niger to increase the aroma of wine. Part I," Enzyme and Microbial Technology, vol. 22, no. 5, pp. 298-304, 1998.

[14] K. Krogh, P. Harris, C. Olsen et al., "Characterization and kinetic analysis of a thermostable GH3 $\beta$-glucosidase from Penicillium brasilianum," Applied Microbiology and Biotechnology, vol. 86, no. 1, pp. 143-154, 2010.

[15] W. Saibi and A. Gargouri, "Purification and biochemical characterization of an atypical $\beta$-glucosidase from Stachybotrys microspora," Journal of Molecular Catalysis B: Enzymatic, vol. 72, no. 3-4, pp. 107-115, 2011.

[16] S.-J. Ma, B. Leng, X.-Q. Xu et al., "Purification and characterization of $\beta$-1,4-glucosidase from Aspergillus glaucus," African Journal of Biotechnology, vol. 10, no. 84, pp. 19607-19614, 2011.

[17] B. Qi, L. Wang, and X. Liu, "Purification and characterization of $\beta$-glucosidase from newly isolated Aspergillus sp. MT-0204," African Journal of Biotechnology, vol. 8, no. 10, pp. 2367-2374, 2009.

[18] T. Watanabe, T. Sato, S. Yoshioka, T. Koshijima, and M. Kuwahara, "Purification and properties of Aspergillus niger $\beta$ glucosidase," European Journal of Biochemistry, vol. 209, no. 2, pp. 651-659, 1992.

[19] M. Raimbault, "General and microbiological aspects of solid substrate fermentation," Electronic Journal of Biotechnology, vol. 1, no. 3, pp. 114-140, 1998.

[20] S. Couri and A. deFarias, "Genetic manipulation of Aspergillus niger for increased synthesis of pectinolytic enzymes," Revista de Microbiologia, vol. 26, pp. 314-317, 1995. 
[21] C. Farinas, M. Loyo, A. Baraldo, P. W. Tardioli, V. B. Neto, and S. Couri, "Finding stable cellulase and xylanase: evaluation of the synergistic effect of $\mathrm{pH}$ and temperature," New Biotechnology, vol. 27, no. 6, pp. 810-815, 2010.

[22] R. Fernandez-Lafuente, C. M. Rosell, V. Rodriguez et al., "Preparation of activated supports containing low $\mathrm{pK}$ amino groups. A new tool for protein immobilization via the carboxyl coupling method," Enzyme and Microbial Technology, vol. 15, no. 7, pp. 546-550, 1993.

[23] J. M. Guisán, "Aldehyde-agarose gels as activated supports for immobilization-stabilization of enzymes," Enzyme and Microbial Technology, vol. 10, no. 6, pp. 375-382, 1988.

[24] P. W. Tardioli, G. M. Zanin, and F. F. de Moraes, "Production of cyclodextrins in a fluidized-bed reactor using cyclodextringlycosyl-transferase," Applied Biochemistry and Biotechnology, vol. 84-86, pp. 1003-1019, 2000.

[25] G. Ramani, B. Meera, C. Vanitha, M. Rao, and P. Gunasekaran, "Production, purification, and characterization of a $\beta$-glucosidase of Penicillium funiculosum NCL1," Applied Biochemistry and Biotechnology, vol. 167, pp. 959-972, 2012.

[26] A. M. Elshafei, M. M. Hassan, N. M. Morsi, and D. H. Elghonamy, "Purification and some kinetic properties of $\beta$ glucosidase from Aspergillus terreus NRRL 265," African Journal of Biotechnology, vol. 10, no. 84, pp. 19556-19569, 2011.

[27] M.-P. Le Traon-Masson and P. Pellerin, "Purification and characterization of two $\beta$-D-glucosidases from an Aspergillus niger enzyme preparation: affinity and specificity toward glucosylated compounds characteristic of the processing of fruits," Enzyme and Microbial Technology, vol. 22, no. 5, pp. 374-382, 1998.

[28] H. Ni, H. Cai, F. Chen, Q. You, A. Xiao, and Y. Wang, "Purification and characterization Of B-D-glucosidase from Aspergillus niger naringinase," Journal of Food Biochemistry, vol. 36, no. 4, pp. 395-404, 2012.

[29] T.-R. Yan and C.-L. Lin, "Purification and characterization of a glucose-tolerant $\beta$-glucosidase from Aspergillus niger CCRC 31494," Bioscience, Biotechnology and Biochemistry, vol. 61, no. 6, pp. 965-970, 1997.

[30] P. W. Tardioli, J. Pedroche, R. L. C. Giordano, R. FernándezLafuente, and J. M. Guisán, "Hydrolysis of proteins by immobilized-stabilized alcalase-glyoxyl agarose," Biotechnology Progress, vol. 19, no. 2, pp. 352-360, 2003.

[31] A. Sadana and J. P. Henley, "Single-step unimolecular nonfirst-order enzyme deactivation kinetics," Biotechnology and Bioengineering, vol. 30, no. 6, pp. 717-723, 1987.

[32] M. M. Bradford, "A rapid and sensitive method for the quantitation of microgram quantities of protein utilizing the principle of protein dye binding," Analytical Biochemistry, vol. 72, no. 1-2, pp. 248-254, 1976.

[33] U. K. Laemmli, "Cleavage of structural proteins during the assembly of the head of bacteriophage T4," Nature, vol. 227, no. 5259, pp. 680-685, 1970.

[34] I. W. Segel, Enzyme Kinetics-Behaviour and Analysis of Rapid Equilibrium and Steady-State Enzyme Systems, John Wiley \& Sons, New York, NY, USA, 1993.

[35] K. Olofsson, M. Bertilsson, and G. Lidén, "A short review on SSF-an interesting process option for ethanol production from lignocellulosic feedstocks," Biotechnology for Biofuels, vol. 1, article 7, 2008.

[36] M. E. Bruins, A. E. M. Janssen, and R. M. Boom, "Thermozymes and their applications: a review of recent literature and patents," Applied Biochemistry and Biotechnology, vol. 90, no. 2, pp. 155186, 2001.
[37] L. Viikari, M. Alapuranen, T. Puranen, J. Vehmaanpera, and M. Siika-Aho, "Thermostable enzymes in lignocellulose hydrolysis," in Biofuels, L. Olsson, Ed., pp. 121-145, Springer, Berlin, Germany, 2007. 

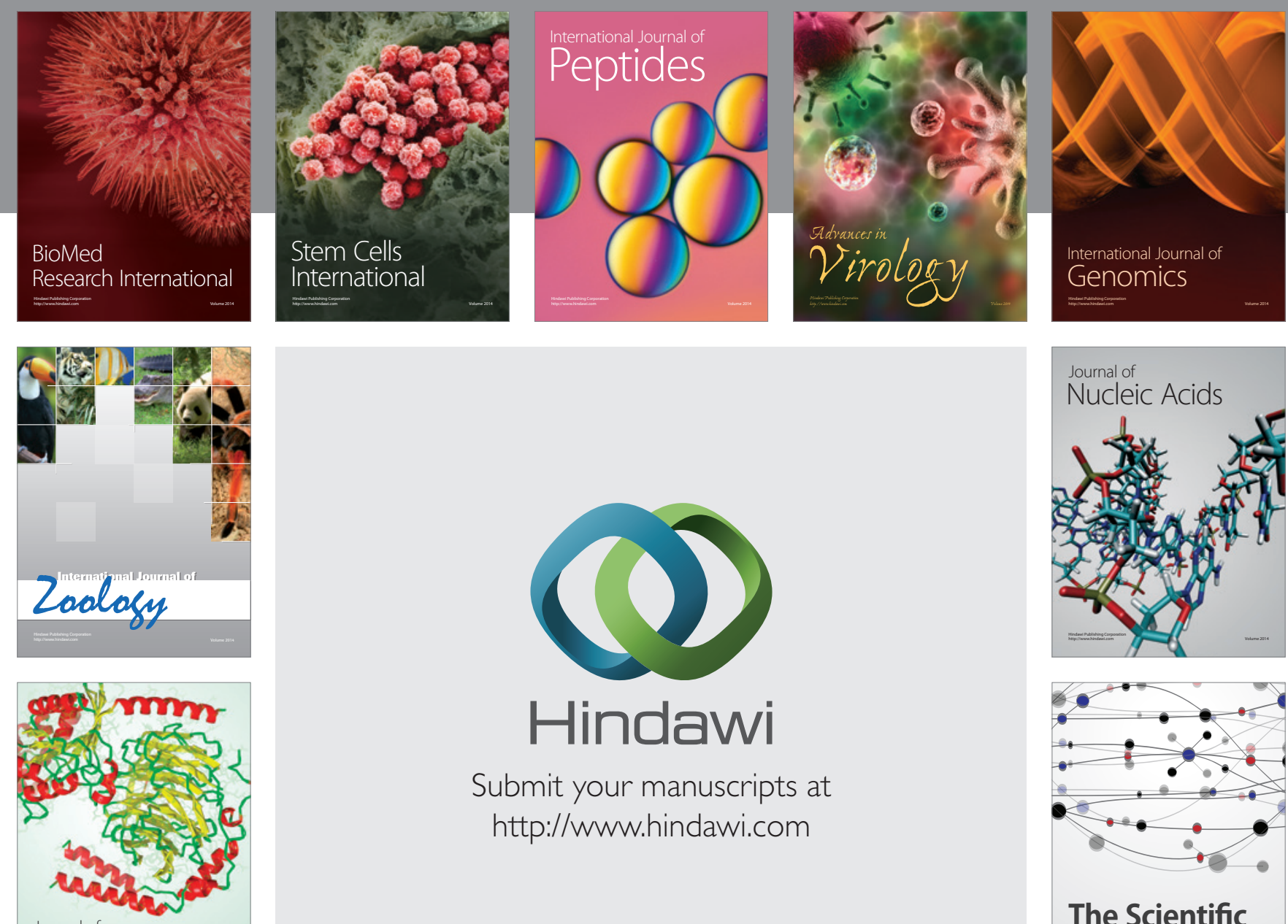

Submit your manuscripts at

http://www.hindawi.com

Journal of
Signal Transduction
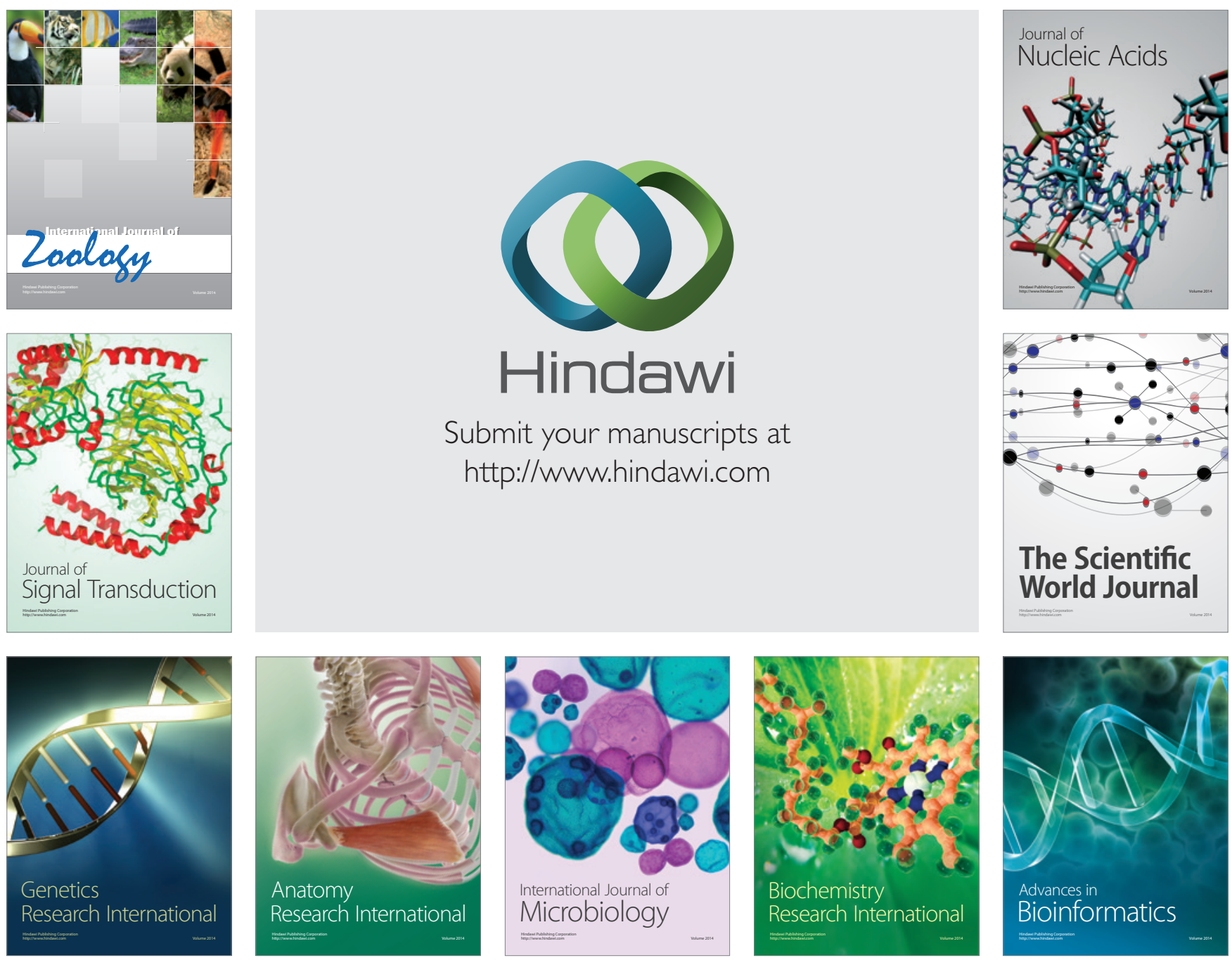

The Scientific World Journal
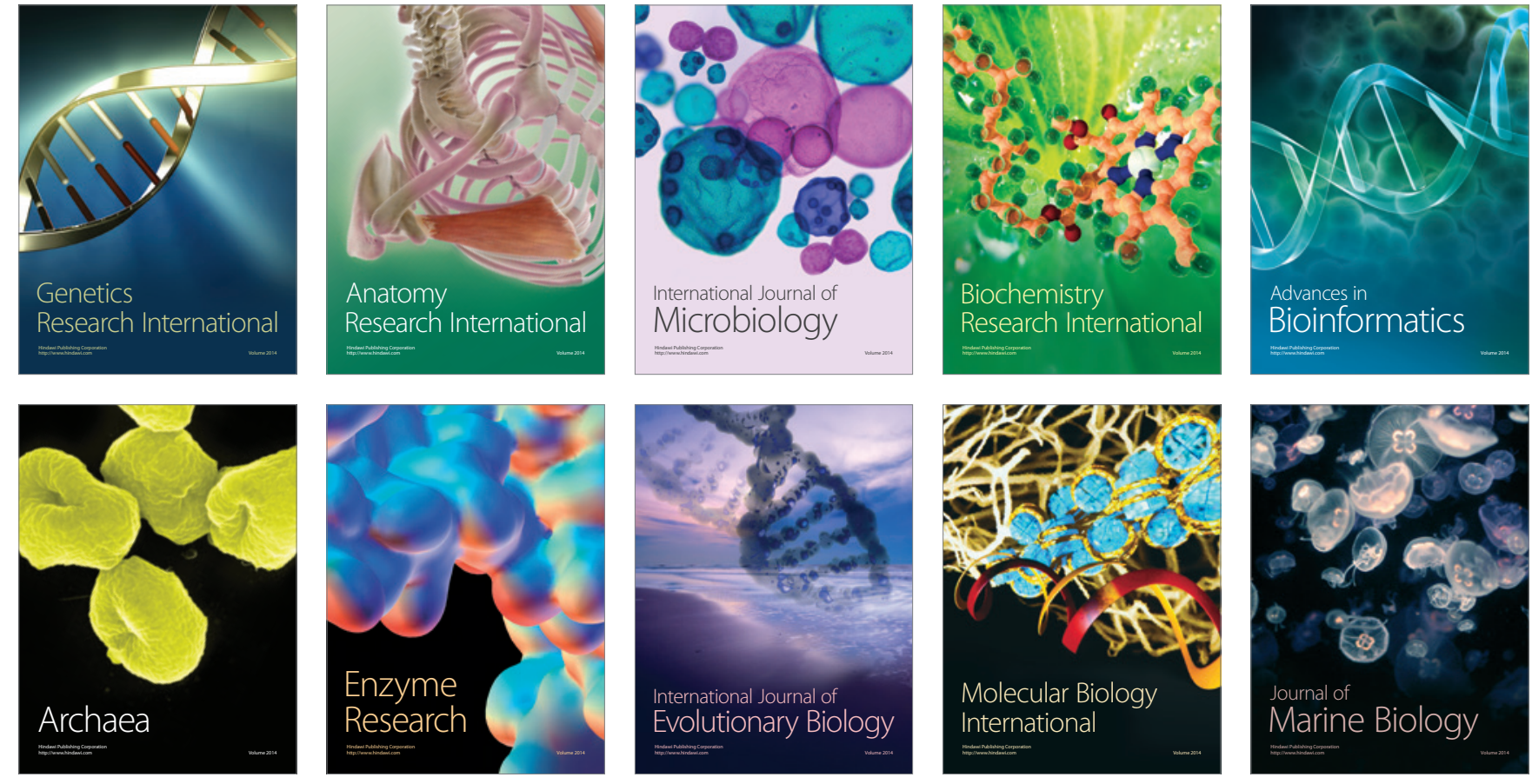